Lepr Rev (2000) 71, 285-308

\title{
The pattern of leprosy-related neuropathy in the AMFES patients in Ethiopia: definitions, incidence, risk factors and outcome
}

\author{
PAUL SAUNDERSON ${ }^{1}$, SHIBRU GEBRE ${ }^{1}$, \\ KETSELA DESTA ${ }^{1}$, PETER BYASS ${ }^{2}$ \\ \& DIANA N. J. LOCKWOOD ${ }^{3}$ \\ ${ }^{1}$ ALERT, PO Box 165, Addis Ababa, Ethiopia \\ ${ }^{2}$ School of Community Health Science, Nottingham University, \\ Nottingham, UK and Department of Public Health and Clinical \\ Medicine, Umeå University, Umeå, Sweden \\ ${ }^{3}$ London School of Hygiene and Tropical Medicine, Keppel Street, \\ London, $U K$
}

Accepted for publication 12 July 2000

Summary The ALERT MDT Field Evaluation Study (AMFES) began in 1988 and followed patients prospectively for up to 10 years after release from treatment (RFT). This paper presents the findings from this cohort with regard to neuropathy and nerve damage. Five hundred and ninety-four new cases of leprosy are included in the study, 300 multibacillary (MB) and 294 paucibacillary (PB) cases. Fifty-five percent of patients had some degree of impairment at diagnosis and a further $73(12 \%)$ developed new nerve function impairment (NFI) after starting multiple drug therapy (MDT). The overall incidence rate for neuropathy was 39 episodes per 100 PYAR in the first year after diagnosis, gradually declining to 12 episodes per 100 PYAR in the sixth year. In those patients without impairment at diagnosis, the incidence rate of neuropathy was 25 episodes per 100 PYAR for MB cases and 11 per 100 PYAR for PB cases in the first year; in 33\% of MB cases whose first episode of neuropathy occurred after diagnosis, that first episode took place after the first year, or after the normal period of treatment with MDT. Seventy-three patients with neuropathy developing after diagnosis are reported more fully: 34 (47\%) had only one nerve involved and of these 25 (73\%) had a single, acute episode of neuropathy. Nine (27\%) had further episodes. Thirty-nine (53\%) had more than one nerve involved and of these $16(41 \%)$ had a single, acute episode, while $23(59 \%)$ had further episodes. The terms 'chronic' and 'recurrent' neuropathy are defined and used to describe the pattern of neuropathy in those with repeated attacks. In patients with no impairment at the start of the study, treatment with steroids resulted in full recovery in $88 \%$ of nerves with acute neuropathy but only $51 \%$ of those with chronic or recurrent neuropathy. The median time to full recovery from acute neuropathy was approximately 6 months, but in a few cases recovery occurred gradually over 2-3 years.

Correspondence to: P. Saunderson, ALM, 1 ALM Way, Greenville SC 29601, USA (e-mail: psaunderson@ leprosy.org) 
Severe neuropathy was less likely to be followed by a complete recovery than mild or moderate neuropathy. Forty-two percent of nerves with acute neuropathy that were not treated with steroids also fully recovered. In the group of patients who were thought to have old, permanent impairments at diagnosis, full recovery of nerve function occurred in $87 / 374(23 \%)$ of the nerves involved. The overall outcome is illustrated by examining the average EHF score for groups of patients. Patients with no new neuropathy after diagnosis show a gradual improvement in their EHF score, while those with any episodes of neuropathy after diagnosis show a gradual deterioration after completion of MDT. Possible explanations for these findings are discussed. Risk factors for neuropathy, for chronic and recurrent neuropathy, and for a poor outcome 5 years after release from treatment, are examined. Impairment at diagnosis was the main risk factor for a poor outcome, accompanied by the occurrence of chronic/recurrent neuropathy or a reversal reaction.

\section{Introduction}

Nerve damage is the most serious consequence of leprosy and it is generally assumed to occur as part of a reactive process, even in the absence of a clinically apparent reaction. Acute inflammation of one or more nerves (acute neuropathy) is frequently associated with a reversal reaction ( $R R$ ), in which there is an increase in cell-mediated immunity to antigen in dermal macrophages and Schwann cells, ${ }^{1}$ with inflammation. Acute neuropathy can also occur with erythema nodosum leprosum (ENL) reactions, in which antigen-antibody complexes are deposited in the tissues, with the activation of complement and local inflammation. ${ }^{2}$ Silent neuropathy is damage occurring without any accompanying reaction or nerve pain/tenderness, but the underlying pathology remains unclear. ${ }^{3}$

Small nerve fibres in the leprosy skin lesions are frequently damaged, but the more important and crippling damage occurs in peripheral nerve trunks, especially when they are near the surface of the skin or in fibro-osseous tunnels. In these situations inflammatory oedema leads to raised intra-neural pressure with nerve compression and ischaemia. ${ }^{4}$

Nerve damage may occur at any time throughout the course of the disease. It may already be present at the time of diagnosis and can occur during and after correct and successful treatment of the infection with multiple drug therapy (MDT) ${ }^{5}$ Richardus found that in Bangladesh $26 \%$ of new patients had nerve function impairment, ${ }^{6}$ while in Nepal the figure was $34 \%{ }^{7}$ During treatment in Thailand, the incidence rate for new nerve damage in those cases without impairment at diagnosis was 1.7 per 100 person years at risk (PYAR) for paucibacillary (PB) patients and 12 per 100 PYAR for multibacillary (MB) patients. ${ }^{8}$ Figures from a recent prospective study in Bangladesh are 1.3 and 24 per 100 PYAR for PB and $\mathrm{MB}$ cases, respectively, although these figures are for all cases, not just those with no impairment at diagnosis; for the latter group, an overall figure of 1.7 episodes of new nerve function impairment per 100 PYAR, is given. ${ }^{9}$ Few studies have followed a large cohort after completion of MDT, so the incidence of nerve damage at that stage has not been quantified.

The assessment of nerve function has received considerable attention in the literature in recent years. Measuring autonomic function is only possible in a laboratory setting at present, ${ }^{10}$ but voluntary muscle testing (VMT) and sensory testing (ST) can be carried out routinely in the clinic setting. ${ }^{11-15}$ The use of slightly different techniques in different programmes, however, makes the detailed comparison of results difficult. 
In the literature it is often difficult to distinguish risk factors for neuropathy from those for reversal (or type 1) reactions. However, several risk factors have been documented, including: bactericidal drug regimens, ${ }^{16}$ attending as a self-reporting case,${ }^{17}$ having a facial patch, as a risk for lagophthalmos, ${ }^{18,19}$ the presence of anti PGL-1 antibodies and a positive lepromin test, ${ }^{19,20}$ during MDT and the subsequent 6 months, ${ }^{21,22}$ extensive disease, indicated by the number of body areas involved, ${ }^{19,22}$ borderline classification, ${ }^{22}$ BCG vaccination, ${ }^{23}$ pregnancy, ${ }^{24}$ enlarged ulnar nerves at diagnosis, ${ }^{19}$ a positive $\mathrm{BI}^{19}$ and impairment present at diagnosis. ${ }^{25}$

The mainstay of treatment of acute neuropathy is a prolonged course of corticosteroids, ${ }^{1}$ although there is not yet agreement on the starting dose and the length of treatment needed. Treatment on an ambulatory basis, prescribed by leprosy control supervisors according to fixed guidelines, was first used in the ALERT control programme in Ethiopia. ${ }^{26}$ Reported results of treatment vary from $11 \%$ to $88 \%$, depending on the nerves involved, the type of neuropathy and length of time that impairment had been present. ${ }^{4}$

A long-term prospective study of new leprosy patients was set up at the All Africa Leprosy, Tuberculosis and Rehabilitation Training Centre (ALERT) in 1988, with the primary task of determining the rate of relapse after MDT. The ALERT MDT Field Evaluation Study (AMFES) as it is known, had the subsidiary objective of determining the incidence of new nerve function impairment and possible risk factors for nerve damage. The findings in relation to this objective are now reported.

\section{Materials and methods}

Six hundred and sixty patients were enrolled in AMFES between March 1988 and March 1993. Ten patients were excluded, either because the diagnosis was changed or the enrolment procedures were incorrectly followed. A further 56 patients, who were relapses after dapsone monotherapy, were not included in this review. Thus 594 new cases were reviewed.

Cases were classified as MB if they were classified clinically as BB, BL or LL in the Ridley-Jopling classification. In addition, BT patients were classified as MB if they had a positive skin smear at any site, although three BT patients with a bacillary index (BI) of 1 were treated as paucibacillary cases in the first year of the study, under earlier guidelines. BT patients with many skin lesions were classified as PB if their smears were negative.

The AMFES patients were examined regularly whilst on MDT (usually monthly) and then at 6-monthly intervals thereafter. These regular reviews consisted of a general examination of the skin and the leprosy lesions, palpation of the peripheral nerve trunks, voluntary muscle testing (VMT) and sensory testing (ST). For the VMT, four muscles were tested (eye closure-facial nerve, little finger out—ulnar nerve, thumb up-median nerve, foot up-peroneal nerve), with the result being 'Strong,' 'Weak' or 'Paralysed.' For the ST, a $10 \mathrm{~g}$ nylon monofilament was used at 10 points on each hand and foot; in the hand, four points were in the distribution of the ulnar nerve and six points in the distribution of the median nerve; all 10 points in the foot are innervated by the posterior tibial nerve.

In AMFES, a clinical definition for neuropathy was used, the most important components being the development of new nerve function impairment (NFI), ${ }^{27}$ nerve pain or tenderness in a nerve trunk. It is assumed that in most cases nerve pain or tenderness alone and nerve function impairment have similar underlying pathologies, and that one will lead on to the other, if not treated. New neuropathy (nerve tenderness and/or new NFI) was managed with steroids, according to a fixed protocol, 'new' meaning that the signs and 
symptoms had been present for less than 6 months. Two steroid regimens were used, both starting with $40 \mathrm{mg}$ of prednisolone daily and decreasing regularly: for multibacillary patients, the regimen was for 24 weeks with 4 weeks at each of the following six doses $(40 \mathrm{mg}, 30 \mathrm{mg}, 20 \mathrm{mg}, 15 \mathrm{mg}, 10 \mathrm{mg}, 5 \mathrm{mg}$ ); for paucibacillary patients, the regimen lasted for 12 weeks only, with 2 weeks at each dosage level. Some patients could be given tailor-made regimens prescribed by physicians, but in general this only occurred when patients were admitted to the ALERT teaching hospital. In the peripheral clinics, further standard courses of steroids could be prescribed for patients developing further episodes of neuropathy, although failure to respond to steroids was an indication for referral to hospital.

The timing of episodes of neuropathy in individual patients was classified retrospectively as follows:

Acute neuropathy:

new ( $<6$ months duration) neuropathy (nerve tenderness and/or new $\mathrm{NFI}$ ), presenting with symptoms of reaction (RR or ENL) or nerve tenderness.

Silent neuropathy: new NFI without accompanying symptoms of reaction (RR or ENL) or nerve tenderness.

Recurrent neuropathy: a subsequent episode of acute neuropathy at least 3 months after cessation of steroids during which time no signs or symptoms of acute neuropathy have been evident.

Chronic neuropathy: further signs of active neuropathy (nerve pain or tenderness or new NFI) within 3 months of cessation of steroids.

The pattern of recurrent neuropathy has not been previously described in the literature. The decision to use a 3-month cut-off for the definition of chronic neuropathy is arbitrary, but, based on the clinical experience of the authors, it appears to be quite a practical cut-off point, in that under this definition there are similar numbers of 'recurrent' and 'chronic' cases.

In many cases, new nerve function impairment occurring after the start of treatment was noted within 6 months of onset and could be treated with steroids. If patients missed followup appointments various methods of tracing and contacting them were used. Some patients, despite these measures, were not examined for a period of longer than 6 months and some of these developed new NFI which would not be treated if apparently present for more than 6 months.

New nerve function impairment is defined as a new loss of two or more points of sensation in the distribution of any one nerve trunk, or a decrease in voluntary muscle strength of one or more steps (in the scale Strong-Weak-Paralysed) for any muscle. A potential source of inconsistency lies in the fact that two points of loss of sensation are needed for the diagnosis of neuropathy, while only one point of LOS is required to move from WHO Impairment Grade 0 to Grade 1 . Those cases who had loss of sensation at one point only, either at the start of treatment or later, are not deemed to have had neuropathy for the purposes of this study, even though they will have had a WHO Impairment Grade of 1 at the times when the loss of sensation is recorded.

For this analysis, the severity of new nerve function impairment was graded on a threepoint scale for each nerve trunk: mild, moderate and severe. Tenderness alone was always graded as mild; two points of loss of sensation in the ulnar or median nerves and three points in the posterior tibial nerve were also graded as mild. Moderate new nerve function impairment implied loss of muscle strength from 'Strong' to 'Weak' and/or loss of sensation 
of 3 points in the ulnar nerve, 3-4 points in the median nerve and 4-7 points in the posterior tibial nerve. Severe new nerve function impairment implied complete loss of muscle strength ('Paralysis') and/or loss of sensation of 4 points in the ulnar nerve, 5-6 points in the median nerve and $8-10$ points in the posterior tibial nerve.

The outcome has been assessed by examining the number (or proportion) of nerves which fully recover from neuropathy. Full recovery means that the nerve in question has returned to normal function as measured by the routine VMT/ST test. For each patient, normal function includes both sides for each particular nerve; thus if there is full recovery of the ulnar nerve, both ulnar nerves have normal function (either or both may have been affected by neuropathy).

Outcome has also been assessed more generally by examining the EHF score over time for groups of patients. This is a summary score of the individual WHO Impairment Grades for the Eyes, Hands and Feet. ${ }^{25,28,29}$ It has the advantages of simplicity and widespread usage and, while inappropriate for following up individual patients, it gives a very helpful overview of the experience of groups of patients.

Longitudinal patient records within this prospective cohort study were managed throughout using dBase software. Analysis used Epi-Info sof tware and logistic regression modelling of multiplicative relative risks was performed using Egret. The possibility of using Cox or Poisson regression was considered: these methods give a lower weight to those cases with a shorter follow-up. We did not consider this to be necessary, as the risk for events is generally highest at the start of treatment; the risks for outcome are, however, only calculated for those with 5-year follow-up data.

\section{Results}

PREVALENCE OF NEUROPATHY AT DIAGNOSIS

Table 1 shows how the 594 new cases enrolled in the study can be grouped according to their initial impairment status and subsequent experience of neuropathy.

Of the group with no impairment at the start and no subsequent neuropathy (195 patients), four patients had steroids for reversal reactions and one had mild erythema nodosum leprosum (ENL), not requiring steroids. This group by definition never had nerve function impairment. In the group with acute neuropathy at the start (47 patients), 21 (45\%) had no further neuropathy while $16(34 \%)$ had recurrent episodes and $10(21 \%)$ had chronic neuropathy.

Table 1. The initial impairment status of new AMFES patients and their subsequent experience of neuropathy

\begin{tabular}{lccc}
\hline Group & PB (\%) & MB (\%) & Total (\%) \\
\hline 1) No impairment at start; never developed neuropathy & $124(43)$ & $71(24)$ & $195(33)$ \\
2) No impairment at start; developed neuropathy later & $16(5)$ & $57(19)$ & $73(12)$ \\
3) Recent impairment at start; treated immediately & $23(8)$ & $24(8)$ & $47(8)$ \\
4) Old impairment at start not treated immediately, & & & \\
$\quad$ but active neuropathy occurred later & $51(17)$ & $87(29)$ & $138(23)$ \\
5) Old impairment at start; no further neuropathy & $80(27)$ & $61(20)$ & $141(24)$ \\
Total enrolled & $294(100)$ & $300(100)$ & $594(100)$ \\
\hline
\end{tabular}




\section{INCIDENCE OF NEUROPATHY DURING THE COURSE OF THE DISEASE}

Episodes of neuropathy are most common at the start of treatment and decrease in frequency thereafter. Significant numbers of episodes occur, however, up to 8 or 9 years after the start of treatment. Figure 1 shows the actual number of episodes of new nerve function impairment by year after the start of treatment, while Figure 2 shows the incidence of new neuropathy by year in episodes per 100 PYAR. Follow-up involved 460 PYAR for the first year of follow-up reducing to 124 PYAR for the seventh year of follow-up. No incidence figures are given for years 8 and 9 , as the number of patients followed is too low to give meaningful results.

In order to allow some comparison with other published data, Figure 3 shows the incidence rate of neuropathy by year in those 268 patients who had no impairment at diagnosis (namely, groups 1 and 2 in Table 1). The highest incidence is 25 episodes per 100 PYAR in MB patients during the first year of treatment. The difference between Figures 2 and 3 is incidence of neuropathy in those with impairment at the start (not shown).

\section{CLASSIFICATION OF NEUROPATHY}

The patients who had no impairment at the start but who subsequently developed neuropathy are perhaps the most interesting group to examine closely, as the full history of their nerve involvement is documented. Table 2 shows the timing of the first episode of neuropathy in this group; one third of MB patients in this group had their first episode after the current end of MDT.

Table 3 shows which nerves were involved in this group of 73 patients and how the neuropathy was classified. The ulnar and posterior tibial nerves-each involved in $52(71 \%)$

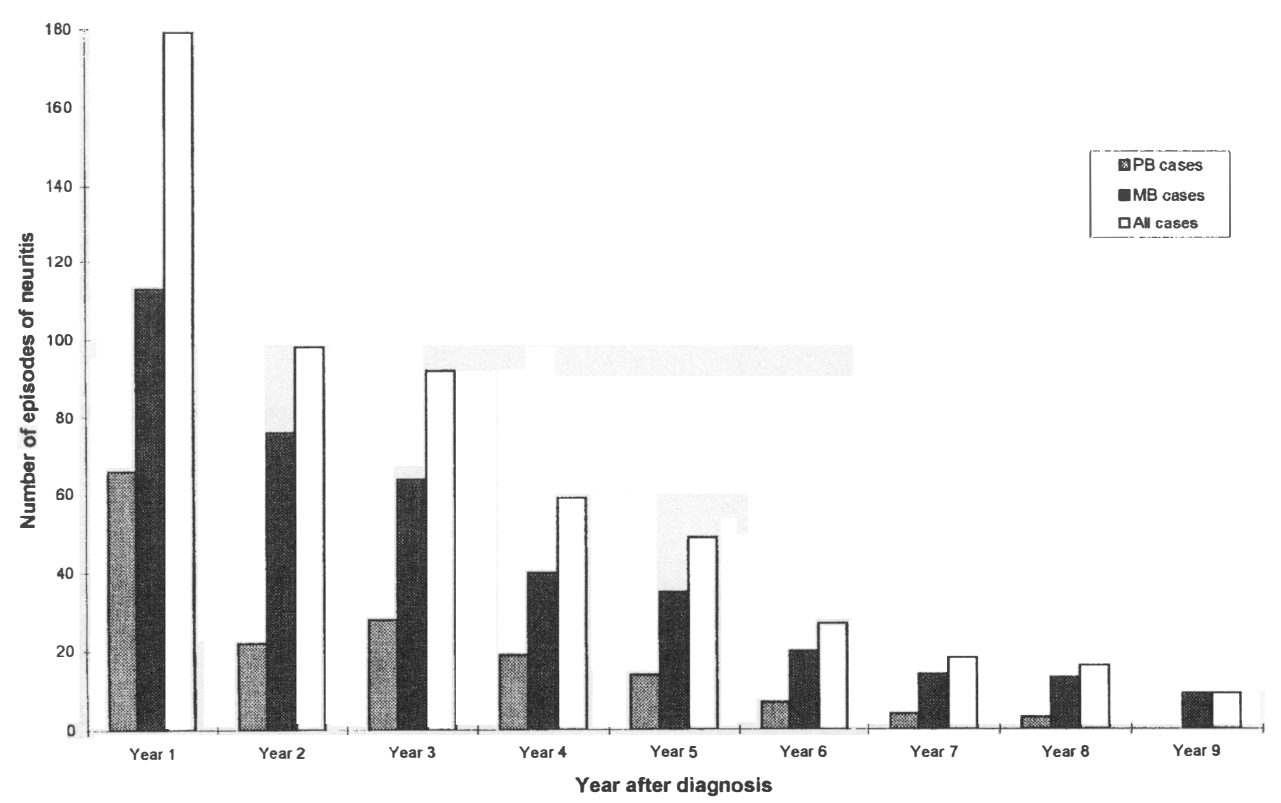

Figure 1. Number of episodes of neuropathy, by year after diagnosis, in 594 patients. 


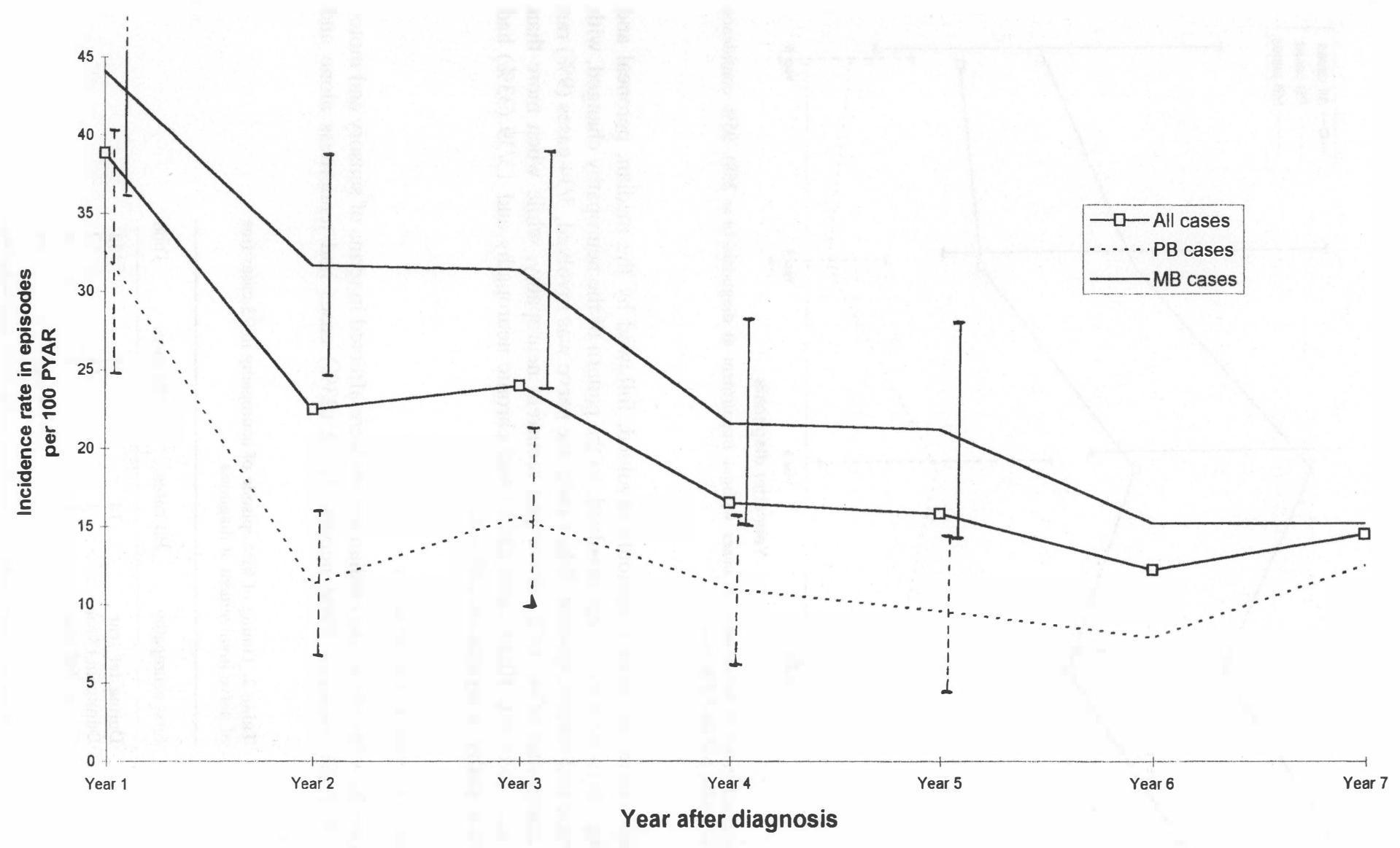

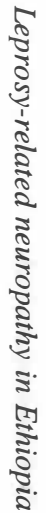

Figure 2. Incidence rates of episodes of neuropathy, by year after diagnosis $(n=594) .95 \%$ confidence intervals are given for MB and PB cases. 


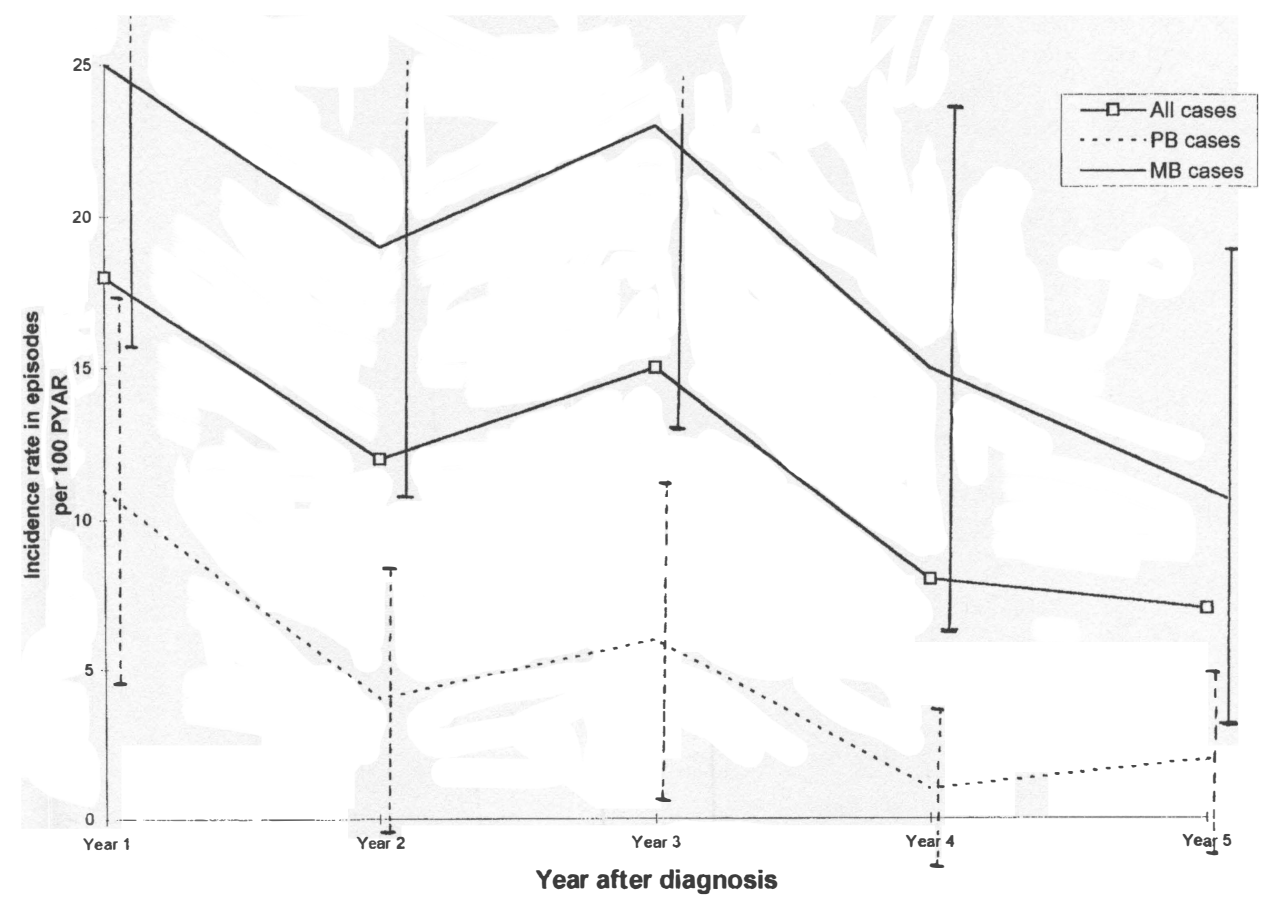

Figure 3. Incidence rates of neuropathy in cases without impairment at diagnosis $(n=268)$. 95\% confidence intervals are given for $\mathrm{MB}$ and $\mathrm{PB}$ cases.

of the cases-were the most commonly involved, followed by the median, peroneal and facial nerves. As more nerves were involved, so the pattern of the neuropathy changed, with more recurrent and chronic disease. When only one nerve was involved, 3/34 cases (9\%) ran a chronic course and 6/34 (18\%) developed recurrent neuropathy, while when more than one nerve was involved, 10/39 cases (26\%) had chronic neuropathy and 13/39 (33\%) had recurrent neuropathy, a significant difference.

\section{SENSORY AND MOTOR INVOLVEMENT}

Table 4 shows how the ulnar and median nerves were affected in terms of sensory and motor modalities. For the posterior tibial nerves, 12/52 (23\%) cases had tenderness alone and

Table 2. Timing of first episode of neuropathy in 73 cases free of nerve involvement at diagnosis

\begin{tabular}{lccr}
\hline First neuropathy & PB cases & MB cases & Total \\
\hline During 1st year & 14 & 38 & 52 \\
During 2nd year & 1 & 11 & 12 \\
During 3rd year & 1 & 8 & 9 \\
& 16 & 57 & 73 \\
\hline
\end{tabular}


Table 3. The pattern of later neuropathy in 73 cases with no impairment at diagnosis. Fifty-seven (78\%) of these cases are MB patients; of the 16 PB patients, 10 had acute, three had recurrent and three had chronic neuropathy

\begin{tabular}{lcccc}
\hline & \multicolumn{2}{c}{ Predominant pattern of neuritis } & \\
\cline { 2 - 4 } Nerve & Acute & Recurrent & Chronic & Total \\
\hline Facial alone & 1 & - & - & 1 \\
Ulnar alone & 11 & 2 & 1 & 14 \\
Median alone & - & - & - & 0 \\
Posterior tibial alone & 13 & 4 & 1 & 18 \\
Peroneal alone & - & - & 3 & 1 \\
Sub-total & 25 & 6 & 2 & $34(47 \%)$ \\
Ulnar \& median & 3 & - & 4 & 5 \\
Ulnar \& post. tibial & 7 & 1 & - & 1 \\
Median \& post. tibial & - & 6 & 1 & 15 \\
Ulnar, median \& post. tibial & 6 & 1 & 10 & 2 \\
Ulnar, median, peroneal \& post. tibial & - & 13 & $13(18 \%)$ & $73(100 \%)$ \\
Sub-total & 16 & $19(26 \%)$ & & $39(53 \%)$ \\
Total & $41(56 \%)$ & & & \\
\end{tabular}

40/52 cases had sensory loss on the sole of the foot. The results of treatment by modality are shown, although the small numbers make interpretation difficult.

\section{SEVERITY OF NEUROPATHY}

Tenderness alone was always given a grading of mild. For the ulnar nerves with sensory or motor involvement, $19 \%$ were graded severe, $79 \%$ were graded moderate and $2 \%$ were graded mild. For the median nerves, $36 \%$ were graded severe, $40 \%$ moderate and $24 \%$ mild. For the posterior tibial nerves, $27 \%$ were graded severe, $38 \%$ moderate and $35 \%$ mild.

Table 4. The involvement of different modalities of the ulnar and median nerves, in 73 cases with no impairment at diagnosis

\begin{tabular}{|c|c|c|c|c|}
\hline \multirow[b]{2}{*}{ Modality } & \multicolumn{2}{|c|}{ Ulnar nerves } & \multicolumn{2}{|c|}{ Median nerves } \\
\hline & $\begin{array}{l}\text { Number }(\%) \text { of } \\
\text { nerves affected }\end{array}$ & $\begin{array}{c}\text { Number (\%) achieving } \\
\text { full recovery }\end{array}$ & $\begin{array}{l}\text { Number }(\%) \text { of } \\
\text { nerves affected }\end{array}$ & $\begin{array}{l}\text { Number (\%) achieving } \\
\text { full recovery }\end{array}$ \\
\hline Tenderness only & $11(21)$ & & $5(22)$ & \\
\hline Sensory only & $3(6)$ & $3(100)$ & $10(43)$ & $7(70)$ \\
\hline Motor only & $28(54)$ & $24(86)$ & $5(22)$ & $5(100)$ \\
\hline Mixed motor \& sensory & $10(19)$ & $4(40)$ & $3(13)$ & $2(67)$ \\
\hline Total & 52 & & 23 & \\
\hline
\end{tabular}

N.B. The categories 'sensory only,' 'motor only' and 'mixed motor and sensory' do not exclude the presence of nerve pain or tenderness. 
SILENT NEUROPATHY

Silent neuropathy occurred at one time or another in $43(59 \%)$ of the 73 cases whose only neuropathy occurred after diagnosis. Not every episode was silent in that 19 of these 43 cases also had a reversal reaction at some time and four had an ENL reaction at some time.

\section{PROGNOSIS AND TIMING OF RECOVERY}

Steroids were given to $167(28 \%)$ of the 594 cases being examined. Twenty-nine (17\%) patients also received steroids in the ALERT hospital. Fifty-four $(32 \%)$ of all those receiving steroids had more than the standard course: 33 had additional standard courses in a rural clinic and 21 of the 29 patients receiving steroids at ALERT had prolonged or repeated courses. Some patients did not receive steroids even though there was an indication in terms of NFI; the reasons for this are not available, but could include contraindications such as a plantar ulcer, logistic problems (for example, prednisolone not available), an impression that the NFI was insignificant, or simply something overlooked in the middle of a busy clinic.

Table 5 indicates the outcome of the various patterns of neuropathy and the time taken to reach full recovery in those that achieved this outcome. The time to recovery for recurrent and chronic neuropathy is the time between the first episode of neuropathy and first date after which there is no further NFI; there may have been times in between these dates when the nerve had normal function, but the neuropathy flared up again later. Some patients with recurrent neuropathy may recover fully from the initial episode, but be left with residual damage after a subsequent episode - these are excluded from the group with full recovery. Some patients experienced a partial recovery of nerve function, with or without steroids, while others developed progressive nerve damage despite treatment with steroids.

Seventeen patients were not given steroids but had 35 episodes of neuropathy noted. Usually the neuropathy was mild. Seven patients fully recovered and of these, two had nerve tenderness without loss of function, one had mild sensory loss and four had muscle weakness (always involving the ulnar nerve, in two cases involving the facial nerve and once the median nerve), which is moderate neuropathy as defined here. Muscle weakness may be difficult to assess, depending as it does on the full co-operation of the patient and it may be that the health worker was not fully convinced of the evidence for neuropathy and therefore withheld steroids at that time.

It may be expected that recovery depends, amongst other factors, on the severity of the neuropathy. Table 6 shows the recovery rates for neuropathy according to pattern and severity. While the numbers are quite small, those with severe neuropathy tend to have a worse prognosis.

\section{NEUROPATHY IN THOSE WITH PRE-EXISTING IMPAIRMENTS}

Table 7 shows the experience of those 47 cases who had NFI at diagnosis (namely, group 3 in Table 1) and were considered to have some hope of recovery, in that at least some of the damage was thought to have occurred within the previous 6 months. They were all treated with steroids at the start of MDT. The median time to full recovery for all 36 episodes of acute neuropathy that recovered was 7 months (range 1-60 months). The median time to full recovery for the 12 cases with recurrent or chronic neuropathy in this group was 35.5 months (range 20-98 months). 
Table 5. The prognosis and timing of recovery in different nerves according to the pattern of neuropathy, in 73 cases with no impairment at diagnosis. The times to recovery are in months

\begin{tabular}{|c|c|c|c|c|c|c|c|c|}
\hline Nerve & No. of cases & Steroids & $\begin{array}{l}\text { Full recovery } \\
\text { from acute } \\
\text { neuropathy }\end{array}$ & $\begin{array}{l}\text { Median time } \\
\text { to recovery } \\
\text { (range) }\end{array}$ & $\begin{array}{l}\text { Full recovery } \\
\text { from recurrent } \\
\text { neuropathy }\end{array}$ & $\begin{array}{c}\text { Median time } \\
\text { to recovery } \\
\text { (range) }\end{array}$ & $\begin{array}{l}\text { Full recovery } \\
\text { from chronic } \\
\text { neuropathy }\end{array}$ & $\begin{array}{c}\text { Median time } \\
\text { to recovery } \\
\text { (range) }\end{array}$ \\
\hline Ulnar & 52 & $\begin{array}{l}\text { Yes } 38 \\
\text { No } 14\end{array}$ & $\begin{array}{r}21 / 22(95 \%) \\
5 / 10(50 \%)\end{array}$ & $\begin{array}{l}6 \cdot 5(1-33) \\
6(5-45)\end{array}$ & $\begin{array}{l}6 / 9(89 \%) \\
2 / 2(100 \%)\end{array}$ & $\begin{array}{l}30(22-57) \\
43(18-69)\end{array}$ & $\begin{array}{l}3 / 7(43 \%) \\
0 / 2(0 \%)\end{array}$ & $\begin{array}{l}14(10-15) \\
-\end{array}$ \\
\hline Median & 23 & $\begin{array}{l}\text { Yes } 18 \\
\text { No } 5\end{array}$ & $\begin{array}{c}12 / 12(100 \%) \\
1 / 4(25 \%)\end{array}$ & $\begin{array}{l}5(3-14) \\
27\end{array}$ & $\begin{array}{l}3 / 5(60 \%) \\
1 / 1(100 \%)\end{array}$ & $\begin{array}{l}26(18-49) \\
32\end{array}$ & $\begin{array}{l}0 / 1(0 \%) \\
-\end{array}$ & $\begin{array}{l}- \\
-\end{array}$ \\
\hline Post. tibial & 52 & $\begin{array}{l}\text { Yes } 36 \\
\text { No } 16\end{array}$ & $\begin{array}{r}15 / 20(75 \%) \\
4 / 10(40 \%)\end{array}$ & $\begin{array}{c}9.5(2-41) \\
10(7-18)\end{array}$ & $\begin{array}{l}4 / 12(33 \%) \\
1 / 6(17 \%)\end{array}$ & $\begin{array}{l}29(13-58) \\
64\end{array}$ & $\begin{array}{l}3 / 4(75 \%) \\
-\end{array}$ & $\begin{array}{l}27(8-54) \\
-\end{array}$ \\
\hline $\begin{array}{l}\text { Peroneal } \\
\text { Facial }\end{array}$ & $\begin{array}{l}3 \\
1\end{array}$ & $\begin{array}{l}\text { Yes } 3 \\
\text { Yes } 1\end{array}$ & $\begin{array}{l}2 / 2(100 \%) \\
0 / 1\end{array}$ & $\begin{array}{l}6(1-11) \\
-\end{array}$ & - & - & $\begin{array}{l}1 / 1(100 \%) \\
-\end{array}$ & $\begin{array}{l}32 \\
-\end{array}$ \\
\hline All nerves & 131 & $\begin{array}{l}\text { Yes } 96 \\
\text { No } 35\end{array}$ & $\begin{array}{l}50 / 57(88 \%) \\
10 / 24(42 \%)\end{array}$ & & $\begin{array}{c}13 / 26(50 \%) \\
4 / 9(44 \%)\end{array}$ & & $\begin{array}{l}7 / 13(54 \%) \\
0 / 2(0 \%)\end{array}$ & \\
\hline
\end{tabular}


Table 6. The rates of full recovery in various nerves according to pattern and severity of neuropathy, in 73 cases with no impairment at diagnosis

\begin{tabular}{|c|c|c|c|c|c|c|c|c|c|c|c|}
\hline \multirow{2}{*}{$\begin{array}{l}\text { Pattern of } \\
\text { neuropathy }\end{array}$} & \multirow{2}{*}{$\begin{array}{l}\text { Severity } \\
\text { Mild }\end{array}$} & \multicolumn{2}{|c|}{$\begin{array}{l}\text { Ulnar } \\
\text { no. } \%\end{array}$} & \multicolumn{2}{|c|}{$\begin{array}{c}\text { Median } \\
\text { no. } \%\end{array}$} & \multicolumn{2}{|c|}{$\begin{array}{c}\text { Post. tib. } \\
\text { no. } \%\end{array}$} & \multirow{2}{*}{$\begin{array}{c}\text { Peroneal } \\
-\end{array}$} & \multirow{2}{*}{$\frac{\text { Facial }}{-}$} & \multicolumn{2}{|c|}{ Total no. \% } \\
\hline & & $2 / 4$ & 50 & $7 / 7$ & 100 & $11 / 14$ & 79 & & & $20 / 25$ & 80 \\
\hline & Moderate & $21 / 23$ & 91 & $4 / 4$ & 100 & $4 / 9$ & 44 & $2 / 2$ & - & $31 / 38$ & 82 \\
\hline & Severe & $3 / 5$ & 60 & $2 / 5$ & 60 & $4 / 7$ & 57 & - & $0 / 1$ & $9 / 18$ & 50 \\
\hline \multirow[t]{3}{*}{ Recurrent } & Mild & $4 / 5$ & 80 & $2 / 2$ & 100 & $1 / 8$ & 13 & - & - & $7 / 15$ & 47 \\
\hline & Moderate & $3 / 5$ & 60 & $1 / 3$ & 33 & $2 / 5$ & 40 & - & - & $6 / 13$ & 46 \\
\hline & Severe & $1 / 1$ & 100 & $1 / 1$ & 100 & $2 / 5$ & 40 & - & - & $4 / 7$ & 57 \\
\hline \multirow[t]{3}{*}{ Chronic } & Mild & $1 / 2$ & 50 & - & - & $2 / 2$ & 100 & - & - & $3 / 4$ & 75 \\
\hline & Moderate & $2 / 5$ & 40 & $0 / 1$ & 0 & $0 / 1$ & 0 & $1 / 1$ & - & $3 / 8$ & 38 \\
\hline & Severe & $0 / 2$ & 0 & - & - & $1 / 1$ & 100 & - & - & $1 / 3$ & 33 \\
\hline Total & & $37 / 52$ & 71 & $17 / 23$ & 74 & $27 / 52$ & 52 & $3 / 3$ & $0 / 1$ & $84 / 131$ & 64 \\
\hline
\end{tabular}

A further group (group 4 in Table 1), with 138 patients, had NFI at the start which was considered too old to be treated with steroids. This group had subsequent episodes of neuropathy, however, as shown in Table 8 . The median time to full recovery for all 52 episodes of acute neuropathy that recovered was 10 months (range 1-57 months). The median time to full recovery for those 37 patients with recurrent or chronic neuropathy or old damage who recovered, was 35 months (range 5-94 months). The overall prognosis in this group was poor, with only $27 \%$ of nerves showing full recovery.

\section{OLD NERVE DAMAGE}

One hundred and forty-one patients had nerve function impairment at diagnosis, which was considered of longer duration than 6 months and was therefore not treated with steroids. This group of patients did not develop any new nerve function impairment over the course of treatment and surveillance. They were therefore never treated with steroids, except for two patients who received steroids for reversal reactions not involving the nerves. It is assumed that these patients have old, stable and more or less permanent nerve damage.

Surprisingly perhaps, a proportion of patients in this category experienced full recovery of some nerves, as indicated in Table 9. Between one-quarter and one-third of

Table 7. The results of treatment with steroids in 47 cases with presumed new nerve function impairment at diagnosis. Numbers and percentages are those that experienced full recovery of that nerve

\begin{tabular}{|c|c|c|c|c|c|c|c|c|c|c|c|}
\hline \multirow{2}{*}{$\begin{array}{l}\text { Pattern of } \\
\text { neuropathy }\end{array}$} & \multicolumn{2}{|c|}{$\begin{array}{l}\text { Ulnar } \\
\text { No. } \%\end{array}$} & \multicolumn{2}{|c|}{$\begin{array}{c}\text { Median } \\
\text { No. } \%\end{array}$} & \multicolumn{2}{|c|}{$\begin{array}{c}\text { Posterior } \\
\text { tibial } \\
\text { No. } \%\end{array}$} & \multicolumn{2}{|c|}{$\begin{array}{l}\text { Peroneal } \\
\text { No. } \%\end{array}$} & \multirow{2}{*}{$\begin{array}{c}\text { Facial } \\
1 / 1\end{array}$} & \multicolumn{2}{|c|}{$\begin{array}{c}\text { Total } \\
\text { No. } \%\end{array}$} \\
\hline & $11 / 15$ & 73 & $10 / 15$ & 67 & $11 / 12$ & 92 & $3 / 3$ & 100 & & $36 / 46$ & 78 \\
\hline Recurrent & $1 / 7$ & 14 & $1 / 7$ & 14 & $2 / 9$ & 22 & - & - & $0 / 1$ & $4 / 24$ & 17 \\
\hline Chronic & $2 / 11$ & 18 & $3 / 6$ & 50 & $2 / 10$ & 20 & $1 / 1$ & 100 & - & $8 / 28$ & 29 \\
\hline Total & $14 / 33$ & 42 & $14 / 28$ & 50 & $15 / 31$ & 48 & $4 / 4$ & 100 & $1 / 2$ & $48 / 98$ & 49 \\
\hline
\end{tabular}


Table 8. The pattern and outcome of neuropathy in those patients with old nerve damage at diagnosis, who subsequently developed new episodes of neuropathy. The numbers and percentages indicate those experiencing full recovery in specific nerves. $(n=138)$

\begin{tabular}{|c|c|c|c|c|c|c|c|c|c|c|c|}
\hline \multirow{2}{*}{$\begin{array}{l}\text { Pattern of } \\
\text { neuropathy }\end{array}$} & \multicolumn{2}{|c|}{$\begin{array}{l}\text { Ulnar } \\
\text { No. \% }\end{array}$} & \multicolumn{2}{|c|}{$\begin{array}{c}\text { Median } \\
\text { No. \% }\end{array}$} & \multicolumn{2}{|c|}{$\begin{array}{c}\text { Posterior } \\
\text { tibial } \\
\text { No. } \%\end{array}$} & \multicolumn{2}{|c|}{$\begin{array}{c}\text { Peroneal } \\
\text { No. } \%\end{array}$} & \multirow{2}{*}{$\frac{\text { Facial }}{2 / 2}$} & \multicolumn{2}{|c|}{$\begin{array}{c}\text { Total } \\
\text { No. } \%\end{array}$} \\
\hline & $24 / 36$ & 67 & $18 / 27$ & 67 & $6 / 14$ & 43 & $2 / 3$ & 67 & & $52 / 82$ & 63 \\
\hline Recurrent & $2 / 13$ & 15 & $11 / 27$ & 41 & $11 / 48$ & 23 & $1 / 8$ & 13 & $1 / 3$ & $26 / 99$ & 26 \\
\hline Chronic & $1 / 24$ & 4 & $1 / 7$ & 14 & $2 / 8$ & 25 & - & - & - & $4 / 39$ & 10 \\
\hline Old damage only* & $1 / 30$ & 3 & $0 / 17$ & - & $1 / 55$ & 2 & $4 / 7$ & 57 & $1 / 1$ & $7 / 110$ & 6 \\
\hline Total & $28 / 103$ & 27 & $30 / 78$ & 38 & $20 / 125$ & 16 & $7 / 18$ & 39 & $4 / 6$ & $89 / 330$ & 27 \\
\hline
\end{tabular}

*Certain nerves had old damage without any further neuropathy, the patient experiencing new neuropathy in other nerve trunks.

nerves with presumed permanent nerve damage showed full recovery over a long period of follow-up.

\section{MEASUREMENT OF OUTCOME}

Outcome was examined by means of the average EHF score for different groups of patients over time. Figure 4 shows the average EHF score at diagnosis, at RFT and 5 years after RFT for four of the groups of patients given in Table 1; group 1, in which neuropathy never occurred and in which the EHF score remained at zero throughout, is not shown.

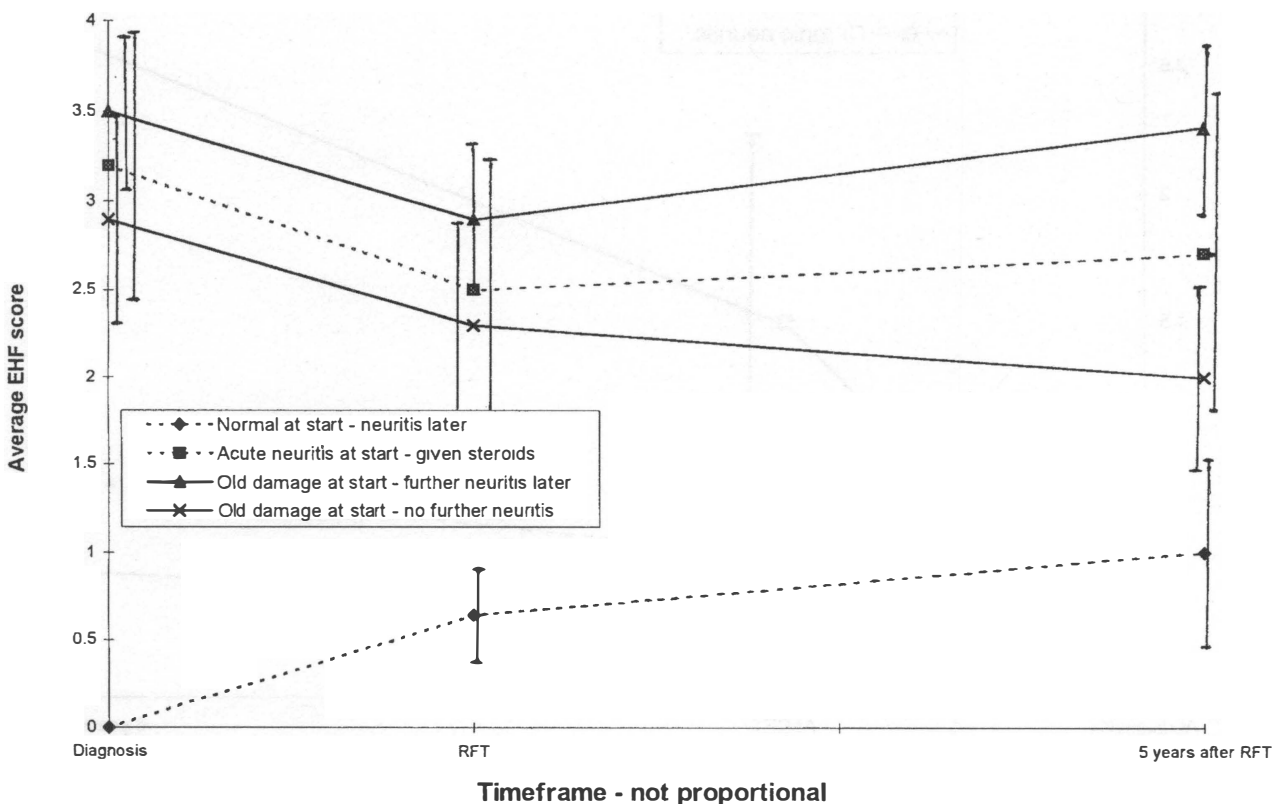

Figure 4. Average EHF scores over time for different categories of patient $(n=185)$. $95 \%$ confidence intervals are given. 
Table 9. Patients with old nerve function impairment experiencing full recovery in specific nerves over time, without steroid treatment $(n=141)$

\begin{tabular}{lccc} 
Nerve & Right side & Left side & Both sides normal at latest review \\
\hline Ulnar & $12 / 39(31 \%)$ & $13 / 43(30 \%)$ & $15 / 56(27 \%)$ \\
Median & $10 / 31(32 \%)$ & $7 / 30(23 \%)$ & $9 / 40(23 \%)$ \\
Peroneal & $0 / 4(0 \%)$ & $2 / 4(50 \%)$ & $2 / 6(33 \%)$ \\
Posterior tibial & $21 / 113(19 \%)$ & $22 / 110(20 \%)$ & $22 / 124(18 \%)$ \\
& & & \\
\hline
\end{tabular}

Groups 3, 4 and 5 all had nerve damage at the start and all improved slightly on average whilst on MDT. Groups 2, 3 and 4 all had active neuropathy at some point after diagnosis and all showed some deterioration on average, in the 5 years after RFT when contact with the health workers was reduced; this may be due to poor self-care or to an on-going low level of neuropathy. Group 5 had old nerve damage at the start and this group continued to improve slowly after RFT. This may indicate better self-care or it may reflect axonal regeneration and spontaneous recovery of some impairments over a long period.

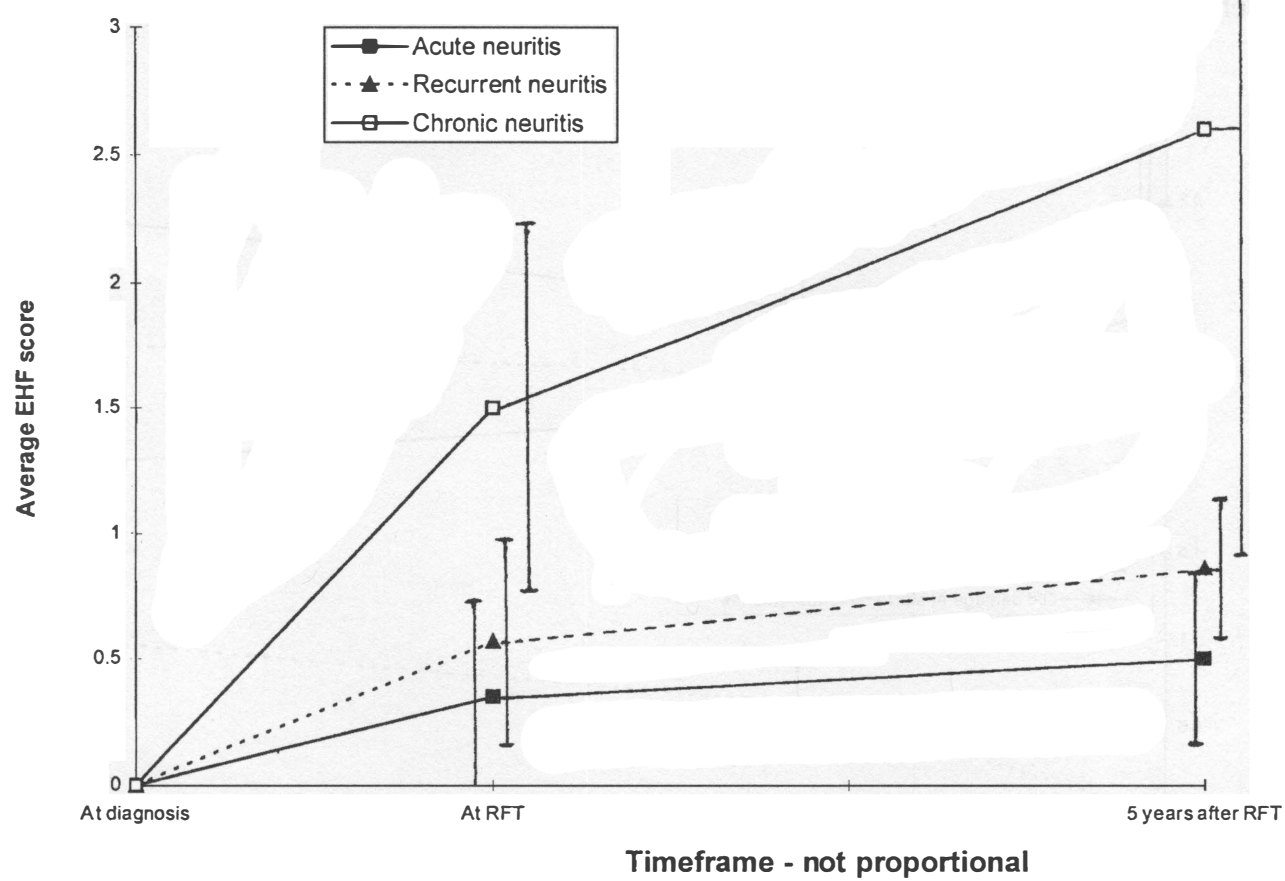

Figure 5. Average EHF scores over time for different types of neuropathy in those cases without impairment at diagnosis $(n=42) .95 \%$ confidence intervals are given. 


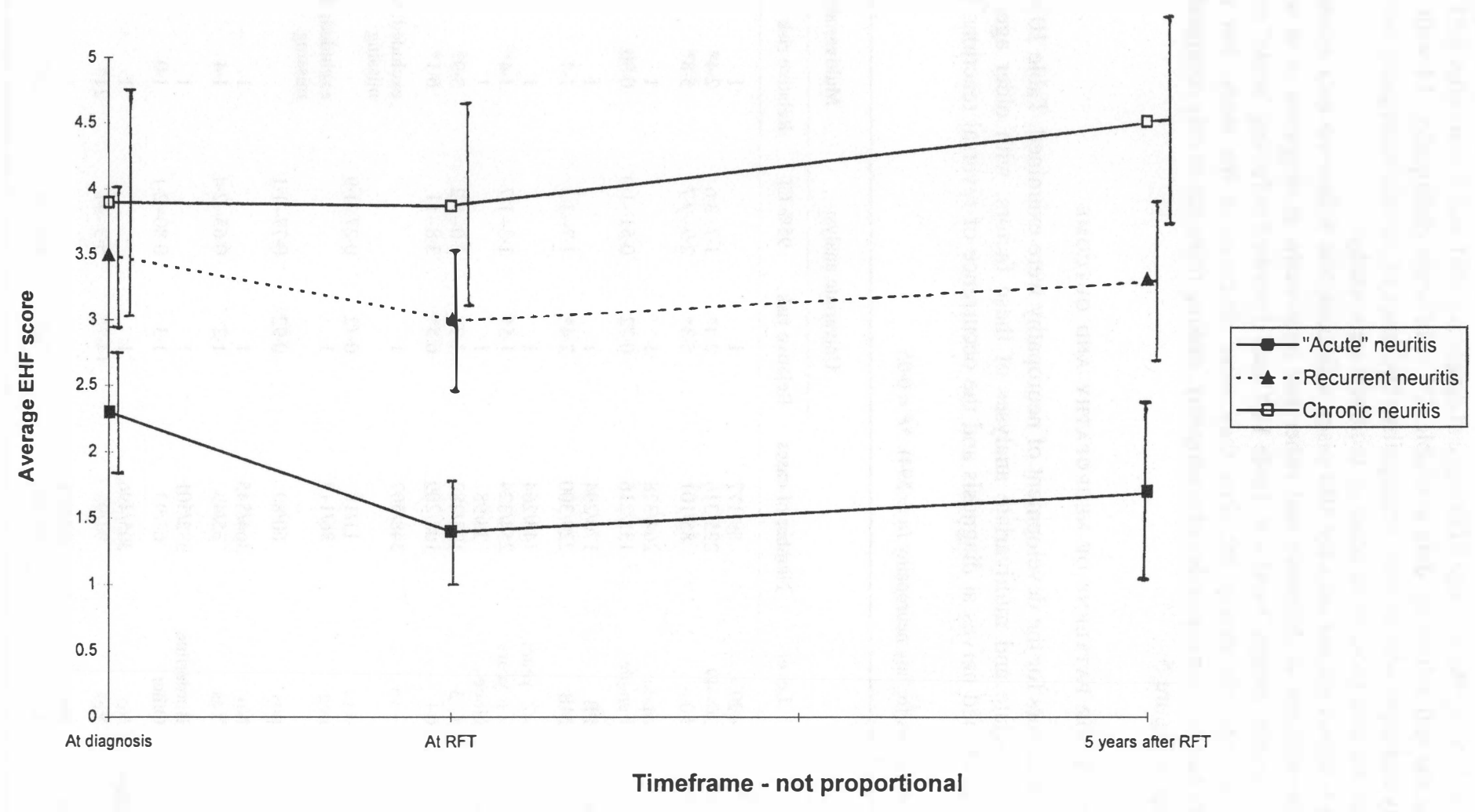

Figure 6. Average EHF scores over time for different types of neuropathy in those with impairment at diagnosis $(n=106)$. 95\% confidence intervals are given. 
Figure 5 looks at the outcome for different types of neuropathy in those without impairment at diagnosis, also using the average EHF score at diagnosis, RFT and 5 years after RFT. Only 42 cases have the full follow-up data available: 20 with acute neuropathy, 14 with recurrent neuropathy and eight with chronic neuropathy. The cases of chronic neuropathy have a much worse outcome than those with acute or recurrent neuropathy.

Figure 6 shows similar data for 106 cases with complete follow-up data amongst those who had impairment at diagnosis and either had neuropathy at diagnosis or at some time thereafter (namely, groups 3 and 4 in Table 1). Cases described as having 'acute' neuropathy had only one episode during the time they were observed in the study, but most had presumably had previous episodes of neuropathy, making them not strictly comparable to the acute group in Figure 5.

\section{RISK FACTORS FOR PATTERNS OF NEUROPATHY AND OUTCOME}

Possible risk factors for the development of neuropathy were examined. Table 10 shows the results of univariate and multivariate analyses of these factors, with older age, delay in diagnosis, thickened nerves at diagnosis and the occurrence of reversal reactions being the

Table 10. Risk factors for any neuropathy $(n=594) .{ }^{*} P<0.05$

\begin{tabular}{|c|c|c|c|c|c|c|}
\hline \multirow[b]{2}{*}{ Factor } & \multirow[b]{2}{*}{ Level } & \multirow[b]{2}{*}{ Number of cases } & \multicolumn{2}{|c|}{ Univariate analysis } & \multicolumn{2}{|c|}{ Multivariate analysis } \\
\hline & & & Relative risk & $95 \% \mathrm{CI}$ & Relative risk & $95 \% \mathrm{CI}$ \\
\hline Age group & $\begin{array}{l}<20 \\
20-49 \\
50+\end{array}$ & $\begin{array}{r}89 / 177 \\
225 / 316 \\
85 / 101\end{array}$ & $\begin{array}{l}1 \\
2 \cdot 4^{*} \\
5 \cdot 3^{*}\end{array}$ & $\begin{array}{l}1 \cdot 7-3 \cdot 6 \\
2 \cdot 9-9.7\end{array}$ & $\begin{array}{l}1 \\
2 \cdot 4^{*} \\
5 \cdot 8^{*}\end{array}$ & $\begin{array}{l}1 \cdot 5-3 \cdot 7 \\
2 \cdot 9-11 \cdot 5\end{array}$ \\
\hline $\operatorname{Sex}$ & $\begin{array}{l}\text { Male } \\
\text { Female }\end{array}$ & $\begin{array}{l}264 / 378 \\
135 / 216\end{array}$ & $\begin{array}{l}1 \\
0 \cdot 72\end{array}$ & $0 \cdot 51-1 \cdot 0$ & $\begin{array}{l}1 \\
0 \cdot 90\end{array}$ & $0.56-1.4$ \\
\hline Leprosy type & $\begin{array}{l}\mathrm{PB} \\
\mathrm{MB}\end{array}$ & $\begin{array}{l}170 / 294 \\
229 / 300\end{array}$ & $\begin{array}{l}1 \\
2 \cdot 4 *\end{array}$ & $1 \cdot 7-3 \cdot 3$ & $\begin{array}{l}1 \\
1 \cdot 4\end{array}$ & $0 \cdot 88-2 \cdot 2$ \\
\hline $\begin{array}{l}\text { Delay } \\
\text { (6 missing) } \\
\text { Thickened nerves }\end{array}$ & $\begin{array}{l}<2 \text { years } \\
2+\text { years } \\
\text { None } \\
1-5 \\
6+\end{array}$ & $\begin{array}{c}143 / 264 \\
254 / 324 \\
38 / 98 \\
193 / 287 \\
168 / 209\end{array}$ & $\begin{array}{l}1 \\
1 \cdot 5^{*} \\
1 \\
3 \cdot 2^{*} \\
6 \cdot 5^{*}\end{array}$ & $\begin{array}{l}1 \cdot 3-1 \cdot 7 \\
2 \cdot 0-5 \cdot 2 \\
3 \cdot 8-11\end{array}$ & $\begin{array}{l}1 \\
1 \cdot 4^{*} \\
1 \\
3 \cdot 9 * \\
6 \cdot 1^{*}\end{array}$ & $\begin{array}{l}1 \cdot 2-1 \cdot 7 \\
2 \cdot 2-6 \cdot 9 \\
3 \cdot 2-11 \cdot 7\end{array}$ \\
\hline HIV & $-\mathrm{ve}$ & $348 / 507$ & 1 & & $\begin{array}{l}\text { excluded; } \\
\text { missing }\end{array}$ & 9 cases \\
\hline $\begin{array}{l}\text { (69 missing) } \\
\text { Lepromin }\end{array}$ & $\begin{array}{l}\text { +ve } \\
\text { neg }\end{array}$ & $\begin{array}{l}11 / 18 \\
86 / 117\end{array}$ & $\begin{array}{l}0 \cdot 72 \\
1\end{array}$ & $0 \cdot 27-1 \cdot 9$ & excluded; & 88 cases \\
\hline (388 missing) & pos & $60 / 89$ & 0.92 & $0 \cdot 77-1 \cdot 1$ & & \\
\hline Pregnancy & $\begin{array}{l}\text { No } \\
\text { Yes }\end{array}$ & $\begin{array}{c}364 / 545 \\
35 / 49\end{array}$ & $\begin{array}{l}1 \\
1 \cdot 2\end{array}$ & $0.65-2 \cdot 4$ & $\begin{array}{l}1 \\
1 \cdot 4\end{array}$ & $0 \cdot 60-3 \cdot 3$ \\
\hline Class & $\begin{array}{l}\text { Borderline } \\
\text { Other }\end{array}$ & $\begin{array}{c}332 / 501 \\
67 / 93\end{array}$ & $\begin{array}{l}1 \\
1 \cdot 3\end{array}$ & $0 \cdot 80-2 \cdot 1$ & $\begin{array}{l}1 \\
1 \cdot 0\end{array}$ & $0.55-1.9$ \\
\hline Reversal reaction & $\begin{array}{l}\text { No } \\
\text { Yes }\end{array}$ & $\begin{array}{c}305 / 496 \\
94 / 98\end{array}$ & $\begin{array}{c}1 \\
14 \cdot 7 *\end{array}$ & $5 \cdot 3-41$ & $\begin{array}{c}1 \\
21^{*}\end{array}$ & $7 \cdot 2-62$ \\
\hline ENL reaction & $\begin{array}{l}\text { No } \\
\text { Yes }\end{array}$ & $\begin{array}{c}384 / 578 \\
15 / 16\end{array}$ & $\begin{array}{l}1 \\
7 \cdot 6^{*}\end{array}$ & $1 \cdot 0-58$ & $\begin{array}{l}1 \\
3 \cdot 7\end{array}$ & $0.43-31$ \\
\hline
\end{tabular}


Table 11. Risk factors for chronic or recurrent neuropathy $(n=594) .{ }^{*} P<0.05$

\begin{tabular}{|c|c|c|c|c|c|c|}
\hline \multirow[b]{2}{*}{ Factor } & \multirow[b]{2}{*}{ Level } & \multirow[b]{2}{*}{ Number of cases } & \multicolumn{2}{|c|}{ Univariate analysis } & \multicolumn{2}{|c|}{ Multivariate analysis } \\
\hline & & & Relative risk & $95 \% \mathrm{CI}$ & Relative risk & $95 \% \mathrm{CI}$ \\
\hline Age group & $\begin{array}{l}<20 \\
20-49 \\
50+\end{array}$ & $\begin{array}{l}38 / 177 \\
73 / 316 \\
28 / 101\end{array}$ & $\begin{array}{l}1 \\
1 \cdot 1 \\
1 \cdot 4\end{array}$ & $\begin{array}{l}0 \cdot 70-1 \cdot 7 \\
0 \cdot 80-2 \cdot 5\end{array}$ & $\begin{array}{l}1 \\
0 \cdot 71 \\
0 \cdot 88\end{array}$ & $\begin{array}{l}0 \cdot 40-1 \cdot 3 \\
0 \cdot 44-1 \cdot 8\end{array}$ \\
\hline Sex & $\begin{array}{l}\text { Male } \\
\text { Female }\end{array}$ & $\begin{array}{l}92 / 378 \\
47 / 216\end{array}$ & $\begin{array}{l}1 \\
0 \cdot 86\end{array}$ & $0 \cdot 58-1 \cdot 3$ & $\begin{array}{l}1 \\
0 \cdot 81\end{array}$ & $0.47-1.4$ \\
\hline Leprosy type & $\begin{array}{l}\mathrm{Pb} \\
\mathrm{Mb}\end{array}$ & $\begin{array}{l}43 / 294 \\
96 / 300\end{array}$ & $\begin{array}{l}1 \\
2 \cdot 8^{*}\end{array}$ & $1 \cdot 8-4 \cdot 2$ & $\begin{array}{l}1 \\
1 \cdot 7 *\end{array}$ & $1 \cdot 0-2 \cdot 9$ \\
\hline $\begin{array}{l}\text { Delay } \\
\text { (6 missing) }\end{array}$ & $\begin{array}{l}<2 \text { years } \\
2+\text { years }\end{array}$ & $\begin{array}{l}50 / 264 \\
89 / 324\end{array}$ & 1 & $1 \cdot 1-2 \cdot 3$ & $\begin{array}{l}1 \\
1 \cdot 1\end{array}$ & $0 \cdot 91-1 \cdot 3$ \\
\hline Thickened nerves & $\begin{array}{l}\text { None } \\
1-5 \\
6+\end{array}$ & $\begin{array}{l}10 / 98 \\
65 / 287 \\
64 / 209\end{array}$ & $\begin{array}{l}1 \\
2 \cdot 6^{*} \\
3 \cdot 9^{*}\end{array}$ & $\begin{array}{l}1 \cdot 3-5 \cdot 2 \\
1 \cdot 9-8 \cdot 0\end{array}$ & $\begin{array}{l}1 \\
2 \cdot 0 \\
1 \cdot 7\end{array}$ & $\begin{array}{l}0 \cdot 85-4 \cdot 5 \\
0 \cdot 71-4 \cdot 0\end{array}$ \\
\hline $\begin{array}{l}\text { HIV } \\
\text { (69 missing) }\end{array}$ & $\begin{array}{l}\text {-ve } \\
\text { +ve }\end{array}$ & $\begin{array}{r}123 / 507 \\
3 / 18\end{array}$ & $\begin{array}{l}1 \\
0 \cdot 6\end{array}$ & $0 \cdot 18-2 \cdot 2$ & \multicolumn{2}{|c|}{$\begin{array}{l}\text { Excluded; } 69 \text { cases } \\
\text { missing }\end{array}$} \\
\hline $\begin{array}{l}\text { Lepromin } \\
\text { (388 missing) }\end{array}$ & $\begin{array}{l}\text { Neg } \\
\text { Pos }\end{array}$ & $\begin{array}{l}42 / 117 \\
23 / 89\end{array}$ & $\begin{array}{l}1 \\
0 \cdot 6\end{array}$ & $0.32-1.2$ & \multicolumn{2}{|c|}{$\begin{array}{l}\text { Excluded; } 388 \text { cases } \\
\text { missing }\end{array}$} \\
\hline EHF on diagnosis & $\begin{array}{l}0 \\
1-2 \\
3+\end{array}$ & $\begin{array}{l}32 / 268 \\
43 / 157 \\
64 / 169\end{array}$ & $\begin{array}{l}1 \\
2 \cdot 8^{*} \\
4 \cdot 5^{*}\end{array}$ & $\begin{array}{l}1 \cdot 7-4 \cdot 6 \\
2 \cdot 8-7 \cdot 3\end{array}$ & $\begin{array}{l}1 \\
2 \cdot 8^{*} \\
6 \cdot 4^{*}\end{array}$ & $\begin{array}{l}1 \cdot 5-5 \cdot 2 \\
3 \cdot 4-12\end{array}$ \\
\hline WHO score & $\begin{array}{l}1 \\
2\end{array}$ & $\begin{array}{l}55 / 185 \\
52 / 141\end{array}$ & $\begin{array}{l}3 \cdot 1^{*} \\
4 \cdot 3^{*}\end{array}$ & $\begin{array}{l}1 \cdot 9-5 \cdot 1 \\
2 \cdot 6-7 \cdot 1\end{array}$ & \multicolumn{2}{|c|}{$\begin{array}{l}\text { Excluded; too closely } \\
\text { correlated with EHF } \\
\text { score }\end{array}$} \\
\hline Class & $\begin{array}{l}\text { Borderline } \\
\text { Other }\end{array}$ & $\begin{array}{c}109 / 501 \\
30 / 93\end{array}$ & $\begin{array}{l}1 \\
1 \cdot 7 *\end{array}$ & $1 \cdot 1-2 \cdot 8$ & $\begin{array}{l}1 \\
1 \cdot 9 *\end{array}$ & $1 \cdot 0-3 \cdot 6$ \\
\hline Pregnancy & $\begin{array}{l}\text { No } \\
\text { Yes }\end{array}$ & $\begin{array}{c}127 / 545 \\
12 / 49\end{array}$ & $\begin{array}{l}1 \\
1 \cdot 1\end{array}$ & $0 \cdot 54-2 \cdot 1$ & $\begin{array}{l}1 \\
1 \cdot 2\end{array}$ & $0 \cdot 47-3 \cdot 1$ \\
\hline Reversal reaction & $\begin{array}{l}\text { No } \\
\text { Yes }\end{array}$ & $\begin{array}{l}80 / 496 \\
59 / 98\end{array}$ & $\begin{array}{l}1 \\
7 \cdot 9 *\end{array}$ & $4 \cdot 9-12 \cdot 6$ & $\begin{array}{c}1 \\
10 \cdot 6^{*}\end{array}$ & $6 \cdot 0-19$ \\
\hline ENL reaction & $\begin{array}{l}\text { No } \\
\text { Yes }\end{array}$ & $\begin{array}{c}127 / 578 \\
12 / 16\end{array}$ & $\begin{array}{c}1 \\
10 \cdot 7 *\end{array}$ & $3 \cdot 4-33$ & $\begin{array}{c}1 \\
11 \cdot 6^{*}\end{array}$ & $3 \cdot 1-43$ \\
\hline
\end{tabular}

significant factors in the multivariate model. It is not surprising that reversal reactions are a risk factor for neuropathy, as the underlying pathology is thought to be the same in many cases, but this study shows no such relationship for ENL reactions. The fact that being classified as MB is not a significant risk factor in this study, may relate to the way patients were classified: almost all BT patients with negative smears were classified as PB, making this a larger group than in other studies. Pregnancy does not appear to be an important risk factor, and while neither HIV nor lepromin status was included in the multivariate model, there is no indication from the univariate analysis that they are significant factors.

Table 11 shows the risk factors for the development of chronic or recurrent neuropathy. In this case leprosy type and the borderline classification were barely significant risk factors, 
Table 12. Risk factors for poor outcome, defined as an EHF score of $>0$ at 5 years after release from treatment $(n=262) . * P<0.05$

\begin{tabular}{|c|c|c|c|c|c|c|}
\hline \multirow[b]{2}{*}{ Factor } & \multirow[b]{2}{*}{ Level } & \multirow[b]{2}{*}{ Number of cases } & \multicolumn{2}{|c|}{ Univariate analysis } & \multicolumn{2}{|c|}{ Multivariate analysis } \\
\hline & & & Relative risk & $95 \% \mathrm{CI}$ & Relative risk & $95 \% \mathrm{CI}$ \\
\hline Age group & $\begin{array}{l}<20 \\
20-49 \\
50+\end{array}$ & $\begin{array}{l}32 / 89 \\
73 / 131 \\
29 / 42\end{array}$ & $\begin{array}{l}1 \\
2 \cdot 2^{*} \\
4 \cdot 0^{*}\end{array}$ & $\begin{array}{l}1 \cdot 3-3.9 \\
1.8-8.7\end{array}$ & $\begin{array}{l}1 \\
1.6 \\
1.6\end{array}$ & $\begin{array}{l}0.69-3.6 \\
0.49-5 \cdot 1\end{array}$ \\
\hline Sex & $\begin{array}{l}\text { Male } \\
\text { Female }\end{array}$ & $\begin{array}{l}91 / 173 \\
43 / 89\end{array}$ & $\begin{array}{l}1 \\
0 \cdot 84\end{array}$ & $0 \cdot 50-1 \cdot 4$ & $\begin{array}{l}1 \\
1 \cdot 3\end{array}$ & $0 \cdot 53-3 \cdot 0$ \\
\hline Leprosy type & $\begin{array}{l}\mathrm{Pb} \\
\mathrm{Mb}\end{array}$ & $\begin{array}{l}57 / 123 \\
77 / 139\end{array}$ & $\begin{array}{l}1 \\
1 \cdot 4\end{array}$ & $0 \cdot 88-2 \cdot 3$ & $\begin{array}{l}1 \\
1 \cdot 1\end{array}$ & $0 \cdot 47-2 \cdot 4$ \\
\hline Delay & $\begin{array}{l}<2 \text { years } \\
2+\text { years }\end{array}$ & $\begin{array}{l}47 / 120 \\
87 / 142\end{array}$ & $\begin{array}{l}1 \\
2 \cdot 5^{*}\end{array}$ & $1 \cdot 5-4 \cdot 0$ & $\begin{array}{l}1 \\
1 \cdot 1\end{array}$ & $0 \cdot 83-1 \cdot 4$ \\
\hline Thickened nerves & $\begin{array}{l}\text { None } \\
1-5 \\
6+\end{array}$ & $\begin{array}{l}12 / 47 \\
62 / 116 \\
60 / 99\end{array}$ & $\begin{array}{l}1 \\
3 \cdot 3 * \\
4 \cdot 5 *\end{array}$ & $\begin{array}{l}1 \cdot 6-7 \cdot 1 \\
2 \cdot 1-9 \cdot 7\end{array}$ & $\begin{array}{l}1 \\
1 \cdot 3 \\
2 \cdot 5\end{array}$ & $\begin{array}{l}0.47-3 \cdot 8 \\
0.82-7 \cdot 8\end{array}$ \\
\hline EHF on diagnosis & $\begin{array}{l}0 \\
1-2 \\
3+\end{array}$ & $\begin{array}{l}17 / 116 \\
46 / 71 \\
71 / 75\end{array}$ & $\begin{array}{c}1 \\
10 \cdot 7 * \\
103^{*}\end{array}$ & $\begin{array}{l}5 \cdot 3-22 \\
33-320\end{array}$ & $\begin{array}{c}1 \\
9 \cdot 1^{*} \\
65^{*}\end{array}$ & $\begin{array}{l}4 \cdot 2-20 \\
18-225\end{array}$ \\
\hline Class & $\begin{array}{l}\mathrm{Bt} / \mathrm{bl} \\
\text { Other }\end{array}$ & $\begin{array}{c}115 / 219 \\
29 / 43\end{array}$ & $\begin{array}{l}1 \\
0 \cdot 72\end{array}$ & $0 \cdot 37-1 \cdot 4$ & $\begin{array}{l}1 \\
0 \cdot 64\end{array}$ & $0 \cdot 21-1.9$ \\
\hline Pregnancy & $\begin{array}{l}\text { No } \\
\text { Yes }\end{array}$ & $\begin{array}{c}124 / 244 \\
10 / 18\end{array}$ & $\begin{array}{l}1 \\
1 \cdot 2\end{array}$ & $0 \cdot 46-3 \cdot 2$ & $\begin{array}{l}1 \\
0 \cdot 81\end{array}$ & $0 \cdot 16-4 \cdot 1$ \\
\hline Reversal reaction & $\begin{array}{l}\text { No } \\
\text { Yes }\end{array}$ & $\begin{array}{l}97 / 203 \\
37 / 59\end{array}$ & $\begin{array}{l}1 \\
1 \cdot 8^{*}\end{array}$ & $1 \cdot 0-3 \cdot 3$ & $\begin{array}{l}1 \\
1 \cdot 3\end{array}$ & $0 \cdot 49-3 \cdot 7$ \\
\hline ENL & $\begin{array}{l}\text { No } \\
\text { Yes }\end{array}$ & $\begin{array}{c}129 / 252 \\
5 / 10\end{array}$ & $\begin{array}{l}1 \\
0.95\end{array}$ & $0 \cdot 27-3 \cdot 4$ & $\begin{array}{l}1 \\
0 \cdot 76\end{array}$ & $0 \cdot 16-3 \cdot 8$ \\
\hline $\begin{array}{l}\text { Any chronic or } \\
\text { recurrent neur. }\end{array}$ & $\begin{array}{l}\text { No } \\
\text { Yes }\end{array}$ & $\begin{array}{l}62 / 169 \\
72 / 93\end{array}$ & $\begin{array}{l}1 \\
5.9 *\end{array}$ & $3 \cdot 3-10 \cdot 6$ & $\begin{array}{l}1 \\
3 \cdot 7 *\end{array}$ & $1 \cdot 5-9 \cdot 2$ \\
\hline
\end{tabular}

while level of impairment at diagnosis and the occurrence of either type of reaction were important factors. It is not at all surprising that impairment at diagnosis is associated with chronic or recurrent neuropathy, in that by definition any further episode of neuropathy is a repeated event. ENL is a chronic condition, so while no link with neuropathy as such was demonstrated, it is not surprising that it is associated with the development of chronic or recurrent neuropathy. In several cases, the chronic neuropathy associated with ENL consisted of prolonged pain and tenderness, with little or no impairment.

Poor outcome was indicated by an EHF score of more than zero, 5 years after release from treatment. Table 12 shows the risk factors for a poor outcome and indicates the importance of impairment at diagnosis and the occurrence of chronic or recurrent neuropathy for the long-term prognosis.

\section{Discussion}

A unique feature of this study is the long period of follow-up for a large cohort of leprosy patients, with regular, detailed reviews of nerve function. The limitations of the study include 
the loss to follow-up of about $30 \%$ of the cohort after completion of treatment. The setting of the study, within the routine services of a vertical leprosy control programme, is both an advantage and a disadvantage. The quality of care and surveillance in a specialised vertical programme means that the data are quite reliable, but the same standard of long-term patient care cannot be expected in an integrated setting. The wider context of the study in Ethiopia, with a high rate of multibacillary patients, a significant delay between the onset of symptoms and diagnosis (on average) ${ }^{30,31}$ and a high rate of impairment at diagnosis, means that the application of these findings in other contexts must be done with caution.

Nerve function assessment was carried out with a methodology suitable for use in the field, ${ }^{15}$ but which is less sensitive than that used in some other studies. In particular, sensory testing was done with a $10 \mathrm{~g}$ monofilament, while other programmes may use a number of graded monofilaments and take insensitivity to a $2 \mathrm{~g}$ monofilament as indicative of impairment. $^{14,32}$ This must be borne in mind when comparing data from different studies, as it affects both the diagnosis of new nerve function impairment and the results of treatment. Thus the results of this study may not be so good if a $2 \mathrm{~g}$ monofilament were used to test for sensation. We suggest, however, that the $10 \mathrm{~g}$ monofilament is a reasonable instrument for field use, probably indicating protective sensation. ${ }^{15}$

Some other studies have used the 6-point MRC scale for voluntary muscle testing, ${ }^{33}$ which may have a similar effect in the determination of full recovery of muscle strength.

The reliability of both sensory testing and voluntary muscle testing is an important consideration. The best methods of testing are still being discussed, but this study used what were thought to be appropriate methods at the time, giving reasonably reliable results in experienced hands. ${ }^{11}$ Nevertheless, it remains the case that a certain proportion of new impairment diagnosed in the field will be due to observer variability, rather than a true change in nerve function and this has to be borne in mind when considering the figures for spontaneous recovery of nerve function.

Fifty-five percent of the AMFES cohort had some impairment at diagnosis, while only $12 \%$ developed neuropathy for the first time after diagnosis (Table 1). Impairment at diagnosis was the major risk factor for permanent nerve damage as indicated by the EHF score 5 years after release from treatment. If the initial score was three or more, the relative risk for a poor outcome was 65 (Table 12). The recent prospective study in Bangladesh found long-standing impairment at diagnosis to be a major risk factor for further neuropathy. ${ }^{9}$ This supports previous findings that early case-finding is the most worthwhile intervention in preventing disability in future leprosy patients. ${ }^{6}$

The incidence of neuropathy in this study is high compared with other published results. There is a gradual decline in incidence rate from a high of 39 episodes per 100 PYAR in the first year after diagnosis to 15 episodes per 100 PYAR in the sixth year (Figure 2). In their comprehensive review of the subject, Lienhardt and Fine found similar figures reported previously from Ethiopia, but generally lower figures reported elsewhere. ${ }^{23}$ Recent figures from Bangladesh are much closer to those found here, with an incidence rate of 34 per 100 PYAR amongst MB patients in the first 6 months after diagnosis, decreasing to 18 per 100 PYAR in the period 18-24 months after diagnosis. ${ }^{9}$ Figures from Thailand show an incidence rate of new nerve function impairment of 1.7 per 100 PYAR in PB cases and 12 per 100 PYAR in MB cases, in those with no impairment at diagnosis. ${ }^{8}$ This compares with figures in this study of 11 per 100 PYAR in PB patients and 25 per 100 PYAR in MB patients in the first year, in those without impairment at diagnosis (Figure 3). Comparisons for PB patients are difficult because of differing definitions of PB cases: in the study in Thailand 
any BT patient with 10 or more lesions was classified as $\mathrm{MB},{ }^{34}$ while in our study BT patients with negative smears were classified as $\mathrm{PB}$, irrespective of the number of lesions. ${ }^{31}$

The timing of neuropathy, shown in Figures 1-3 and Table 2, is by no means limited to the period of MDT when patients are more closely observed by health staff. New neuropathy, even in those who have never had any impairment before, occurred after the 12-month period of MDT in 19 of $57 \mathrm{MB}$ cases (33\%), exactly the same figure being found in Bangladesh. ${ }^{9}$ New neuropathy occurred in both the second and the third years after diagnosis, while further episodes continued to occur throughout the period of follow-up, with a gradually declining incidence. It is therefore imperative that patients are taught to recognise for themselves the signs of new nerve damage and what is available to them in terms of treatment. The only group that could possibly be excluded from this requirement are those PB patients with no impairment at any time before release from treatment, especially if the PB group is more narrowly defined than in this study.

In those who developed neuropathy after diagnosis, the involvement of more than one nerve led to an increased risk of developing chronic or recurrent neuropathy (Table 3 ). In those who developed a chronic or recurrent pattern of neuropathy, the prognosis was worse and the time taken to recover was greatly prolonged (Table 5).

Silent neuropathy was common, occurring at some point in $59 \%$ of cases without impairment at diagnosis in this study. Van Brakel found it in $13 \%$ of new patients at some point, ${ }^{3}$ while Croft et al. found $86 \%$ of all new episodes of neuropathy were silent. ${ }^{9}$

The results of treatment with steroids depend on various factors. If the impairment has been present for longer than 6 months, the results are poor ${ }^{35}$ and more severe impairments have a worse outcome than moderate cases. ${ }^{36}$ In this study, very high rates of full recovery $(88 \%)$ were achieved in those cases with acute neuropathy treated with steroids (Table 5). In the Bangladesh study already quoted, the overall rate of full recovery from acute neuropathy treated with prednisolone was $37 \%$, with some improvement in $67 \% .{ }^{37}$ Various reasons as to why these rates are higher than in other reported studies can be advanced. Firstly, this is a very selective group with no impairment at diagnosis, being carefully watched for the first signs of neuropathy - in many studies, including the Bangladesh study, all cases of new or acute neuropathy are grouped together. It is clear that a patient with impairment at diagnosis has already had neuropathy and therefore a subsequent episode should, according to the definitions used here, be termed recurrent or chronic. Secondly, the use of the $10 \mathrm{~g}$ monofilament as the assessment tool for sensation, and the 3-point scale for voluntary muscle testing, may be less sensitive than the tools used in other studies, especially hospital-based studies. Thus someone with full recovery in our study could have a mild residual impairment if a more sensitive test were used.

A third possible reason relates to the period of follow-up. In our study follow-up was for up to 10 years after completion of MDT, with many cases of neuropathy achieving recovery more than a year after treatment with prednisolone. In the Bangladesh study, results are so far only reported up to 12 months after the start of prednisolone for neuropathy. ${ }^{37}$ Interestingly in Bangladesh, it was noted that sensory recovery at 12 months was less in those with a short history of impairment, than in those with a longer history; if the natural history of the condition is long in some cases, say 12-18 months, those that started later may recover later and perhaps those with a short history will show further recovery with further follow-up.

If the neuropathy was recurrent or chronic the results were less good. Table 6 shows that severity of impairment was an important factor, with only $50 \%$ of severe acute neuropathy 
cases recovering fully. Table 5 also indicates that the time taken to reach full recovery may be rather long, certainly longer than the standard course of steroids. Studies that assess the results of treatment immediately such a standardised course is completed will underestimate the amount of recovery.

Forty-two percent of episodes of acute neuropathy recovered fully without steroids. Surprisingly, this also applies to between a quarter and one-third of those nerves in which the damage was assumed to be permanent because of its long-standing nature. Schreuder noted partial improvement in $14 \%$ of his cases in Thailand with impairment at diagnosis but no further neuropathy and no treatment with steroids, ${ }^{8}$ while Croft et al. found full recovery in $17 \%$ of untreated cases, with some improvement in $62 \%{ }^{37}$ This suggests that studies looking at the effectiveness of steroids, or other forms of treatment for neuropathy, must not assume that all improvement is the result of a specific intervention.

The number of cases examined in detail here makes it difficult to show a difference in prognosis between motor and sensory impairment, but more severe neuropathy has a worse outcome. Croft et al. found no association between outcome and type of nerve damage, nor its duration or severity. ${ }^{37}$

Studies are being developed to look for new treatments for neuropathy. ${ }^{4}$ This study has shown that certain groups of patients do very well with steroids, but that others do not. The development of chronic or recurrent neuropathy incurs a much worse prognosis and any new treatment could be targeted to that group. After treatment for neuropathy with a standard course of steroids, patients may continue to improve over several more months (Table 5), but any further deterioration in nerve function by definition indicates some form of chronic or recurrent neuropathy and demands more aggressive treatment.

Figures 4-6 show the long-term trends in EHF score for different groups of patients. The gradual improvement in those with old, permanent damage is clearly shown in Figure 4. Similarly, a continued deterioration in those who have had any neuropathy at or after diagnosis is apparent. Effective self-care in the former group and poor self-care in the latter group, seems a contradictory and unlikely explanation for these findings. It seems more likely that there is ongoing neuropathy in those showing deterioration and axonal regeneration in some of those with permanent damage.

In Figure 5, the small group without impairment at diagnosis are illustrated. The much worse prognosis in those with chronic neuropathy is demonstrated. Figure 6, however, shows that those with impairment at diagnosis generally remain with much the same level of impairment over the course of the disease.

Risk factors are examined in Tables 10-12. Not all known risk factors could be examined in this study, but some clinical risk factors have been confirmed and quantified, while others are shown to be less important. Both univariate and multivariate analyses were carried out. The multivariate analysis looks at all the factors together for the best combined explanation of risk and therefore reduces the error from confounding of factors. The univariate analysis is quick to do, so is a useful start, but is more subject to error. The factors significantly associated with the development of neuropathy (including neuropathy occurring before diagnosis, as evidenced by impairment when first seen) were: older age, a delay in diagnosis, a higher number of nerves noted to be thickened at diagnosis and the occurrence of reversal reactions. Classification and the occurrence of ENL reactions were not risk factors in this study, nor were pregnancy, HIV positivity and lepromin positivity.

Risk factors for developing chronic or recurrent neuropathy were also examined (Table 11) with classification, impairment at diagnosis and the occurrence of either reversal 
or ENL reactions being significant. Neither HIV positivity nor pregnancy was a significant risk factor.

Poor outcome is examined in Table 12, which indicates how important impairment at diagnosis and chronic or recurrent neuropathy are for the long-term prognosis. The fact that pregnancy has not been found to be a risk factor for either neuropathy in any form, or a poor outcome, means that female patients can be reassured about the safety of becoming pregnant at any stage of the disease. Since a good long-term outcome in people who get leprosy is one of the main goals of all leprosy control work, these results suggest that health promotion for early diagnosis, and the diagnosis, management and prevention of chronic and recurrent neuropathy, are the main challenges for those currently working in leprosy control programmes.

\section{Conclusions and recommendations}

1. The vast majority of all nerve damage occurs before diagnosis: $82 \%$ of all patients who eventually get nerve damage have some damage at diagnosis and an EHF score of 3 or more at diagnosis gives a 65 -fold risk of a poor outcome. Therefore, public education for early diagnosis should be the highest priority in leprosy control programmes.

2. Management of acute neuropathy with steroids can achieve very good results: $88 \%$ of acute neuropathy episodes in those without previous impairment recover fully when treated with a standardized steroid regimen; training of health workers to do this effectively in peripheral clinics is a worthwhile development.

3. Chronic and recurrent neuropathy need to be identified: chronic and recurrent neuropathy are risk factors for a poor outcome. Patients who show any deterioration after treatment with a standard regimen should be referred for more intensive treatment with steroids, or newer types of treatment that may become available. Guidelines for managing these cases need to be developed.

4. Neuropathy can occur for the first time after MDT has been completed: $33 \%$ of MB cases with no impairment at diagnosis who eventually get neuropathy, do so after the 1-year period of MDT and many others continue to get episodes of neuropathy for years after completing MDT; patient awareness, self-examination and self-referral must be fostered. Provision for the assessment and management of these cases must be made.

5. Recovery of apparently permanent nerve damage may occur: up to one-third of nerves with long-standing damage may spontaneously recover over a period of several years; prevention of further damage and disability during that process is important.

6. Risk factors identified in this study include: for neuropathy, older age, delay in diagnosis, thickened nerves at diagnosis and reversal reactions; for chronic or recurrent neuropathy, classification, impairment at diagnosis, reversal and ENL reactions; and for a poor outcome: impairment at diagnosis and chronic or recurrent neuropathy.

\section{Acknowledgements}

We thank the staff of the ALERT Leprosy/TB Control Division for their dedication and perseverance in managing the patients and collecting data over so many years. The financial support of ILEP, through Netherlands Leprosy Relief (NLR), has been constant throughout the 12 years of the study and is gratefully acknowledged. We also thank ALERT as a whole for institutional and administrative support. 


\section{References}

${ }^{1}$ Britton WJ. The management of leprosy reversal reactions (Editorial). Lepr Rev, 1998; 69: 225-234.

2 Lockwood DNJ. The management of erythema nodosum leprosum: current and future options (Editorial). Lepr Rev, 1996; 67: 253-259.

${ }^{3}$ van Brakel WH, Khawas IB. Silent neuropathy in leprosy: an epidemiological description. Lepr Rev, 1994; 65 : 350-360.

${ }^{4}$ Lockwood DNJ. Kellersberger Memorial Lecture 1998: nerve damage in leprosy: a problem for patients, doctors and scientists. Ethiop Med J, 1998; 37: 133-140.

${ }^{5}$ Rose P, Waters MF. Reversal reactions in leprosy and their management (Editorial). Lepr Rev, 1991; 62: 113-121.

${ }^{6}$ Richardus JH, Finlay KM, Croft RP, Smith WC. Nerve function impairment in leprosy at diagnosis and at completion of MDT: a retrospective cohort study of 786 patients in Bangladesh. Lepr Rev, 1996; 67: 297-305.

7 van Brakel WH, Khawas IB. Nerve damage in leprosy: an epidemiological and clinical study of 396 patients in west Nepal-Part 1. Definitions, methods and frequencies. Lepr Rev, 1994; 65: 204-221.

${ }^{8}$ Schreuder PA. The occurrence of reactions and impairments in leprosy: experience in the leprosy control program of three provinces in northeastern Thailand, 1978-1995. III. Neural and other impairments. Int J Lepr, 1998; 66: $170-181$.

${ }^{9}$ Croft RP, Nicholls PG, Richardus JH, Smith WC. Incidence rates of acute nerve function impairment in leprosy: a prospective cohort analysis after 24 months (The Bangladesh Acute Nerve Damage Study). Lepr Rev, 2000; 71 : $18-33$.

10 Wilder-Smith E, Wilder-Smith A, Egger M. Peripheral autonomic nerve dysfunction in asymptomatic leprosy contacts. J Neurol Sci, 1997; 150: 33-38.

${ }^{11}$ Lienhardt C, Currie H, Wheeler JG. Inter-observer variability in the assessment of nerve function in leprosy patients in Ethiopia. Int J Lepr, 1995; 63: 62-76.

12 Kets CM, van Leerdam ME, van Brakel WH et al. Reference values for touch sensibility thresholds in healthy Nepalese volunteers. Lepr Rev, 1996; 67: 28-38.

13 Brandsma JW, van Brakel WH, Anderson AM et al. Intertester reliability of manual muscle strength testing in leprosy patients. Lepr Rev, 1998; 69: 257-266.

14 van Brakel WH, Kets CM, van Leerdam ME et al. Functional sensibility of the hand in leprosy patients. Lepr Rev, 1997; 68: 25-37.

15 Saunderson PR, Gebre S, Currie H, Byass P. Sensory testing of the hand in leprosy. (Letter). Lepr Rev, 1997; 68: $252-254$.

16 Groenen G, Janssens L, Kayembe T et al. Prospective study on the relationship between intensive bactericidal therapy and leprosy reactions. Int J Lepr, 1986; 54: 236-244.

17 Boerrigter G, Ponnighaus JM, Fine PEM. Preliminary appraisal of a WHO-recommended multiple drug regimen in paucibacillary leprosy patients in Malawi. Int J Lepr, 1988; 56: 406-417.

18 Hogeweg M, Kiran KU, Suneetha S. The significance of facial patches and type I reaction for the development of facial nerve damage in leprosy. A retrospective study among 1226 paucibacillary leprosy patients. Lepr Rev, 1991; 62: 143-149.

19 Roche PW, Le Master J, Butlin CR. Risk factors for type 1 reactions in leprosy. Int J Lepr, 1997; 65: 450-455.

20 Roche PW, Theuvenet WJ, Britton WJ. Risk factors for type-1 reactions in borderline leprosy patients. Lancet, 1991; 338: 654-657.

21 Becx-Bleumink M, Berhe D. Occurrence of reactions, their diagnosis and management in leprosy patients treated with multidrug therapy; experience in the leprosy control program of the All Africa Leprosy and Rehabilitation Training Center (ALERT) in Ethiopia. Int J Lepr, 1992; 60: 173-184.

22 van Brakel WH, Khawas IB, Lucas SB. Reactions in leprosy: an epidemiological study of 386 patients in west Nepal. Lepr Rev, 1994; 65: 190-203.

${ }^{23}$ Lienhardt C, Fine PEM. Type 1 reaction, neuritis and disability in leprosy. What is the current epidemiological situation? Lepr Rev, 1994; 65: 9-33.

${ }^{24}$ Lockwood DNJ, Sinha HH. Pregnancy and leprosy: a comprehensive literature review. Int J Lepr, 1999; 67: 6-12.

25 Reed NK, van Brakel WH, Reed DS. Progress of impairment scores following commencement of chemotherapy in multibacillary leprosy patients. Int J Lepr, 1997; 65: 328-336.

26 Becx-Bleumink M, Berhe D, Mannetje W. The management of nerve damage in the leprosy control services (Editorial). Lepr Rev, 1990; 61: 1-11.

27 de Rijk AJ, Gebre S, Byass P, Berhanu T. Field evaluation of WHO-MDT of fixed duration, at ALERT, Ethiopia: the AMFES project, part 2. Reactions and neuritis during and af ter MDT in PB and MB leprosy patients. Lepr Rev, 1994; 65: 320-332.

28 de Rijk AJ, Gebre S, Byass P, Berhanu T. Field evaluation of WHO-MDT of fixed duration at ALERT, Ethiopia: the AMFES project-I. MDT course completion, case-holding and another score for disability grading. Lepr Rev, 1994; 65: 305-319.

29 van Brakel WH, Reed NK, Reed DS. Grading impairment in leprosy. Lepr Rev, 1999; 70: 180-188. 
${ }^{30}$ Bekri W, Gebre S, Mengiste A et al. Delay in presentation and start of treatment in leprosy patients: a case-control study of disabled and non-disabled patients in three different settings in Ethiopia. Int J Lepr, 1998; 66: 1-9.

${ }^{31}$ Meima A, Saunderson PR, Gebre S et al. Factors associated with impairments in new leprosy patients: the AMFES cohort. Lepr Rev, 1999; 70: 189-203.

32 de Rijk AJ, Byass P. Field comparison of 10-g and 1-g filaments for the sensory testing of hands in Ethiopian leprosy patients. Lepr Rev, 1994; 65: 333-340.

33 Croft RP, Richardus JH, Nicholls PG, Smith WC. Nerve function impairment in leprosy: design, methodology and intake status of a prospective cohort study of 2664 new leprosy cases in Bangladesh (The Bangladesh Acute Nerve Damage Study). Lepr Rev, 1999; 70: 140-159.

34 Schreuder PA. The occurrence of reactions and impairments in leprosy: experience in the Leprosy Control Program of three Provinces in Northeastern Thailand, 1978-1995. 1. Overview of the study. Int J Lepr, 1998; 66: 149-158.

35 Croft RP, Richardus JH, Smith WC. Field treatment of acute nerve function impairment in leprosy using a standardized corticosteroid regimen-first year's experience with 100 patients. Lepr Rev, 1997; 68: 316-325.

36 van Brakel WH, Khawas IB. Nerve function impairment in leprosy: an epidemiological and clinical study-Part 2: results of steroid treatment. Lepr Rev, 1996; 67: 104-118.

37 Croft RP, Nicholls PG, Richardus JH, Smith WC. The treatment of acute nerve function impairment in leprosy: results from a prospective cohort study in Bangladesh. Lepr Rev, 2000; 71: 154-168. 